\title{
The Impact and Dynamics of External Debt Servicing on Economic Growth of Ethiopia
}

\author{
Getachew Mulat Kebede \\ Aksum University Po Box: 1010
}

\begin{abstract}
The objective of this study was to examine the impact and dynamics of external debt servicing on economic growth of Ethiopia using data for the period from 1982 to 2018. Hence, to achieve its objective the researcher uses both descriptive and econometric method of data analysis. The analysis was based on secondary data retrieve from World Bank (WB) and Central Statistics Authority (CSA). The econometrics model tests such as unit root test, cointegration test and diagnostic test have been done. The study suggests that both long run and short-run indicates that both growth of gross government expenditure and growth of capital formation have significant positive impact on economic growth of Ethiopia in the long run. Based on the finding of this paper it recommends, the authorities were responsible to promote the growth of capital formation to enhance economic growth of Ethiopia by implementing an appropriate policy.
\end{abstract}

DOI: $10.7176 / \mathrm{JESD} / 10-15-05$

Publication date: August $31^{\text {st }} 2019$

\section{1 .Backgroud of the Study}

Ethiopia has grown at a rate between $8 \%$ and $11 \%$ annually for more than a decade and the country is the fifthfastest growing economy among the 188 International Monetary Fund (IMF) member countries. This growth has been driven by sustained progress in the agricultural and service sectors. Almost $80 \%$ of Ethiopia's population is still employed in the agricultural sector, but services have surpassed agriculture as the principal source of GDP. Under Ethiopia's constitution, the state owns all land and provides long-term leases to tenants. Since 2005, the Ethiopian government has introduced a system to register traditional land use rights and provide certificates documenting these rights. Initial surveys show that land-use certificates have significantly increased the willingness of farmers to invest in improvements on their land, from terracing to irrigation. Ethiopia's export earnings are led by the services sector - primarily Ethiopian airlines followed by several commodities. While coffee remains the largest foreign exchange earner, Ethiopia is diversifying exports and commodities such as gold, sesame, chat, livestock and horticulture products are becoming increasingly important. The presence of external debt may constrain growth via two channels. First highly indebted economy will discorage private investers from investing by expecting ahigher rate of taxing their output to repay the loan and hence results alower level of economic growth. Second the repayments of debt service results in presure on the government budget and may reduce public investment and social spending which inturn reduce economic growth(Idermit and Brain,2005 Cited in Assmamaw, 2014/15).To many observers, debt is anew form of colonialism, different kinds of North-South relation, in which western creditors, International Financial Institution (IFIs) and other leaders held the poor countries in perpetual state of domination control. Communities, have holds and people's live are systematically destroyed using debt as amajor weapon. However to others capital movment i.e external debt is asssumed to be asource of economic growth by stimulating investment to those who can not buy their own internal capital(Abinet,2005).

This paper is considering capital formation as explanatory variable to show economic growth of Ethiopia. On the other hand,Dijksta and Hermes(2001)in case of 104 highly indebted poor countries, Sereivx \& Samy (2001) for 53 lower and middle income countries, Karagol(2002) in Turkey, Wijeweera, Doller \& Pathberiya (2005) in Sri Lanka, Adesola(2009) in Nigeria, Malik, HayatMK \& HayatMH (2010) in Pakistan, Atique \& Malik (2012) in Pakistan studied about the impact of external debt and external debt servicing on economic growth in those areas. Khan, Batool \& Mehomood (2013) is also studdied about impact of external debt servicing on per capita income growth rate in the case of Pakistan economy. Apart from the previous research works, this research is study about the impact of external debt servicing on economic growth in the case of Ethiopian economy.

\section{Objective of the study}

The main purpose of this paper is to examine the impact of external debt servicing on economic growth of Ethiopia. Specifically, this study aims at estimating the the way how external debt servicing influences economic growth of Ethiopia and to assess trend of external debt in Ethiopian context

\section{Review of Related Literature}

Many researchers have undertaken a variety of researches regarding the impact of external debt servicing on economic growth of Ethiopia. Nevertheless, they did not agree as to the specific variables that causes in the country. This implies that the issue of $i$ external debt servicing on economic growth requires an intensive study with sound 
methodology so that it may be easy to control and predict it.

Wijeweera (2005) empirically studies the checked relationship between external debt and Growth National Product (GNP) for Sri Lanka by applying Engel and Granger (1987) co-integration and extracellular matrix (ECM). The results suggest that the sign of debt servicing coefficient was negative, and capital stock and human capital were having positive relation in the short run and the long run. Ayadi (2008) investigated the impact of indebtedness and debt service obligations on economic growth of Nigerian and South African economies. On his study, he attempted to explore a linear as well as non-linear effect of debt on growth and investment using both ordinary least squares (OLS) and generalize least squares (GLS) in his analysis. He finds that external debt and servicing requirements have negative effects on both countries economic growth.

Melese (2005) by using structural macro-economic model, found that all debt burden indicators have a negative relationship with economic growth during the period from 1970-2002. Haile (2005), using conventional tests, argued that the Ethiopian debt is sustainable. Moreover, on the basis of the unit root and co-integration tests, he concludes that given the attendant flow of revenue and expenditures, the current outstanding debt is sustainable. Similarly, AFRoDAD (2006) examined that due to the momentous debt relief that has been extended to Ethiopia following the HIPC and MDRI initiatives, the Ethiopian debt has significantly declined relative to what it was until 2004.Hailemariam (2010) investigated the existence of long run relationship between external debt and growth in Ethiopia. He explores that the current level of external debt flow has a positive while the past debt accumulation has a negative impact on growth and private investment. Hailemariam (2011) investigated that total debt servicing has a significant negative impact on economic growth implying that debt overhang occurs in the long run periods. Siraj (2014) using Co-integration and Vector Error Correction approaches and time series data between the period 1971 to 2011,the result shows that Public and private investments have significant short run and long run positive impact on economic growth of Ethiopia. Mulugieta (2014) use Johansen maximum likelihood techniques of estimation and time series data of the period 1983/84 to 2012/13, the regression result indicates that terms of trade have a positive contribution to real GDP both in the short-run and long-run. Private investment also has a positive contribution to real GDP in the long-run but insignificant in the short-run. Moreover, the estimated short-run growth equation also illustrate that the current flow of external debt has a positive contribution to real GDP while; the long-run estimation result reveal that stock of external debt has a negative impact on economic growth. This confirms the existence of debt overhang hypothesis in the Ethiopian economy. However, total debt servicing has a significant and negative impact on economic growth of Ethiopia both in the long-run and shortrun. Assmamaw (2014/15) use ordinary least square (OLS) estimation technique and time series data from 1985 to 2013 and the result shows that external debt and foreign aid have not significant impact on economic growth of Ethiopian economy. Apart from the previous research works, this research is study about the impact of external debt servicing on economic growth in the case of Ethiopian economy.

\section{Research Methodology}

As the primary focus of this paper is to analyze the impact of external debt servicing on economic growth of Ethiopia, the econometric model is specified to facilitate the test of hypothesis that whether explanatory variables cause of external debt servicing on economic growth of Ethiopia.

The key macro-economic variables which are incorporated in the model are gross domestic product (GDP), term of trade (TOT), foreign aid, external debt, external debt servicing, gross government expenditure, and capital formation, even if there are many variables which are affects economic growth.

Therefore, the mathematical regression equation is specified based on Abenet's (2005) equation as a bench mark by making some improvement.

$$
g \mathrm{GDP}=\mathrm{F}(\mathrm{gED}, \mathrm{g} \text { EDS, gFA, TOT, gGGE, gCAF, })
$$

Then the econometric equation is formulated as follows:

$$
g G D P_{\mathrm{t}}=\beta_{0}+\beta_{1} g \mathrm{ED}_{\mathrm{t}}+\beta_{2} g \mathrm{EDS}_{\mathrm{t}}+\beta_{3} g \mathrm{FA}_{\mathrm{t}}+\beta_{4} \mathrm{TOT}_{\mathrm{t}}+\beta_{5} g G G E+\beta_{6} g \mathrm{CAF}_{\mathrm{t}}+\varepsilon_{\mathrm{t}}
$$

Where, $\beta_{0}, \beta_{1} \ldots \beta_{6}$ are parameters to be estimate themodel.

$\mathrm{gGDP}_{\mathrm{t}}=$ growth of Gross Domestic Product at time t,

$\mathrm{gED}_{\mathrm{t}}=$ growth of Stock of External Debt at time $\mathrm{t}$,

$\mathrm{gEDS}_{\mathrm{t}}=$ growth of External Debt servicing at time $\mathrm{t}$,

$\mathrm{gFA}_{\mathrm{t}}=$ growth of Foreign Aid at time $\mathrm{t}$,

$\mathrm{TOT}_{\mathrm{t}}=$ Terms of Trade at time $\mathrm{t}$,

$\mathrm{gGGE}_{\mathrm{t}}=$ growth of Gross Government Expenditure at time t,

$\mathrm{gCAF}_{\mathrm{t}}=$ growth of Capital Formation at time $\mathrm{t}, \mathrm{\varepsilon t}=$ the error term.

\section{Results and Discussion}

\section{Unit Root Test Stationary Test}

The fundamental contribution of this test is to question the validity of the stationary assumptions of classical regression technique in light of the time series property of macro variables. The first step in time series econometric 
analysis is to carry out unit root test on the variables. The test examines whether the data series is stationary or not. Working with non-stationary variables leads to spurious regression results from which further inference is meaningless. To conduct the test for stationary of the series, conventional Augmented Dickey-Fuller (ADF) test is used with and without a trend. The null hypothesis in these tests maintains that the series under investigation has unit root. On the other hand, alternative hypothesis claims that the series is stationary.

Table 4.1 Stationarity test (at level)

\begin{tabular}{|c|c|c|c|}
\hline \multicolumn{4}{|c|}{ Augmented Ducky fuller test } \\
\hline \multirow{2}{*}{\multicolumn{2}{|c|}{ Variables }} & \multicolumn{2}{|c|}{ Test statistics } \\
\hline & & Constant & Constant+Trend \\
\hline \multicolumn{2}{|l|}{ gGDP } & -3.304 & -3.837 \\
\hline \multicolumn{2}{|l|}{ gEDS } & -5.347 & -5.453 \\
\hline \multicolumn{2}{|l|}{ gED } & -3.971 & -4.030 \\
\hline \multicolumn{2}{|l|}{ gFA } & -3.064 & -3.104 \\
\hline \multicolumn{2}{|l|}{ gCAF } & -3.123 & -8.137 \\
\hline \multicolumn{2}{|l|}{ gGGE } & -4.983 & -5.591 \\
\hline \multicolumn{2}{|l|}{ TOT } & -2.300 & -3.601 \\
\hline \multirow{2}{*}{$\begin{array}{l}\text { Critical } \\
\text { values }\end{array}$} & $1 \%$ & -3.65 & -4.27 \\
\hline & $5 \%$ & -2.96 & -3.56 \\
\hline
\end{tabular}

Source: Ox Metrics 6.1 and stata 14 (Authors computation) 2019

From table 4.1 the Augmented Ducky Fuller (ADF) and (PP) test shows that the dependent variable gGDP is stationary at 5\% critical value at level. Both gEDS and gGGE are stationary at $1 \%$ critical values with constant and constant plus trend at level. gFA is stationary with constant at 5\%critical value by ADF test. gCAF is stationary at $5 \%$ with constant and at $1 \%$ with constant plus trend ADF. gED also stationary at $1 \%$ with constant and at $5 \%$ with constant plus trend in ADF test stationary, TOT is stationary in constant plus trend

\subsection{Estimation result analysis}

5.1.1Long run Estimation result

Table 4.4 long run estimation result

\begin{tabular}{|l|l|l|l|l|lc|}
\hline Variable & Coef. & Std. Err. & T & P $>$ t & [95\% Conf. Interval] \\
\hline gED & 0.0113738 & .0673018 & 0.17 & 0.8670 & -.1267182 & .1494658 \\
\hline gEDS & -0.065492 & .0480421 & -1.36 & 0.184 & -.1640664 & .0330823 \\
\hline gFA & .0257674 & .0656519 & 0.39 & 0.698 & -.1089391 & .1604739 \\
\hline TOT & -27.82514 & 22.0758 & -1.26 & 0.218 & -73.12093 & 17.47065 \\
\hline gGGE & .5422571 & .1209983 & 4.48 & 0.000 & .2939891 & .7905252 \\
\hline gCAF & 0.1840922 & .0811819 & 2.27 & 0.032 & 0175206 & .3506638 \\
\hline cons & 14.88279 & 11.44086 & 1.30 & 0.204 & -8.591917 & 38.35749 \\
\hline & R-squared $=0.5766$ Adj R-squared $=0.4825 \mathrm{~F}(6$, & $27)=$ & 6.13 Prob $>\mathrm{F}=0.0004$ \\
\hline
\end{tabular}

Source: stata 14 (Authors computation) 2019

$\mathrm{gGDP}=14.88279+0.0113738 \mathrm{gED}-0.065492 \mathrm{gEDS}+0.0257674 \mathrm{gFA}-$

$$
\begin{array}{lll}
(11.44086)(.0673018) \quad(0480421) & (0.0656519)
\end{array}
$$

$27.82514 \mathrm{TOT}+0.5422571 \mathrm{gGGE}+0.1840922 \mathrm{gCAF}$

(22.0758) (0.1209983) (0.0811819)

The growth of capital formation which is peroxide by gross investment has a positive impact on Ethiopian economic growth and statistically significant at 5 percent level of significance. This study's result is consistence with study of (Abel, 2014) in Ethiopia.

The coefficient of growth of capital formation ( $\mathrm{gCAF}$ ) is 0.1840922 . This indicates that, in the long run, holding other things constant, a one percent change in growth of capital formation about 0.184 percent change in the growth of gross domestic product (gGDP) during the study period. From this the nation that needs to meet the objective economic development needs capital formation. Capital formation is a prerequisite to an increase capital stock of a nation with investment in social and economic infrastructures. The growth of gross government expenditure has a significant positive impact on the economic growth of Ethiopia it is statistically significant at $1 \%$ level of significance. The coefficient growth of gross government expenditure (gGGE) is 0.5423 . This implies that, in the long run, holding other things constant, a one percent change in growth of gross government expenditure results 0.54 percent change in the growth of GDP proportionally.

\section{Conclusion and Recommendations}

In Ethiopia, in the face of series macroeconomic problems, which includes, huge debt servicing, persistence current 
account and budget deficits, and currency devaluation, inflationary process is high. Given this macroeconomic environment, analyzing external debt servicing on economic growth by using annual data from 1982-2018.process is important.

The study shows that external debt servicing and economic growth has no uniform trend from period to period. That means if external debt servicing is increase in some period but, the gross domestic product decrease and viceversa. The study also shows the trend of debt stock and debt servicing are cyclical and usually the growth of the two variables are opposed each other. This can be concluding that when the country performance is improved to repay the debt burden results decreasing the amount of external debt stock accumulation in the country and viceversa. Ethiopia debt service saving ratio is one major indicator of the country debt burden that hinder its economic growth and development. The analysis in this particular study found out that external debt servicing has statistically insignificant effect on Ethiopian economic growth both in long run and short run. This estimation result however does not warrant concluding that external debt servicing is insignificant to economic growth. Among explanatory variables the growth of capital formation and growth of gross government expenditure have statistically positive impact on the economic growth of Ethiopia in the long run in the study period. However, other explanatory variables are statistically insignificant to affect the economic growth of Ethiopia based on the model developed in this study paper.

Based on the findings of the study, the following measures may help on the issue of external debt servicing on economic growth of Ethiopia.

* The government should promote the growth of capital formation to enhance economic growth of Ethiopia by implementing an appropriate policy.

* The government should use effective government expenditure and spend it on productive areas rather than for consumption and military purpose to accelerate economic growth of Ethiopia.

* The Ethiopian government should promote exportation of domestic products as a high exchange rate will make our goods more attractive in the foreign market and will increase foreign exchange earnings.

* From figure 4.1 accumulated debt stocks creates a debt overhang which explodes the confidence of both foreign and domestic private investors who are sensitive to uncertainties. These uncertainties are emanated from anticipation of future tax liabilities for debt servicing. This in turn will lead them to invest in any other countries where tax burden is less or believed to be credit worthy. Hence, in order to spur investors ${ }^{\text {ee }}$ confidence the government should create credibility in policy including political will to reforms.

\section{Reference}

Abinet, G. (2005). The Impact of External Debt on Economic Growth in Ethiopia, Thesis submitted to the schools of Graduate studies of Addis Ababa University, Ethiopia, (unpublished).

Adesola, W. (2009).Debt servicing and economic growth in Nigeria: An empirical investigation. Glob .J. of social science $8(2)$

Assmamaw,G. (2014/15). Effect of external debt on economic growth of Ethiopia, paper submitted to Graduation of BA degree Debre Markos University, Ethiopia (unpublished).

Atique, M and Malik, A. (2012). Impact domestic and external debt on the economic growth of Pakistan, University of Punjab

Ayadi, S.M. (2008). The Impact of External Debt on Economic Growth: A comparative study of Nigeria and South Africa, Journal of Sustainable Development in Africa, 3 (2008).

Befkadu, D. (1992). Growth and Foreign Debt: The Ethiopian experience1964-86, AERC Research paper 13, Nairobi.

Dijkstra, G. and Hermes, N. (2001). The uncertainty of debt service payments and economic growth of HIPCs: Is there a case for debt relief? WIDER Discussion Paper 2001/122. Helsinki: UNU/WIDER.

Haile, K. (2005). Arithmetic of debt sustainability and Its Fiscal Policy Implications in the Case of Ethiopia, Ethiopian Economic Policy Research Institute Working Paper, No.1.

Hailemariam, A. (2010). Impact of External Debt on Economic Growth and private Investment in Ethiopia a Thesis submitted to the school of Graduate studies of Addis Ababa University, Addis Ababa (unpublished).

Hailemariam, A. (2011). Impact of external debt on economic growth and private investment in Ethiopia: Paper submitted to the 9thinternational conference on Ethiopian economy.

Hassen, H. (2002). The impact of aid and external debt on growth and investments: University of Nottingham, credit research paper No, 02/26.

Karagol, E. (2002). The Causality Analysis of External Debt Service and GNP: The Case of Turkey. Central bank review vol. 1

Kaupapa, R. (2016). Why are terms of trade important? past, present and future development in New Zealand's terms of trade.

Malik, S., Hayat, MK., Hayat, MH. ( 2010). External Debt and Economic Growth: Empirical Evidence from 
Pakistan, International Research Journal of Finance and Economics.

Melese, G. (2005). External Debt and Economic Growth in Ethiopia,African Institute for Economic Development and Planning (IDEP), Dakar (Senegal)

Menbere, W. (2004,June). Debt overhang and economic growth: An econometric Reference

Wijeweera, A., Dollery, B., Pathberiya, P. (2005). Economic Growth and External Debt Servicing: A Cointegration Analysis of Sri Lanka, Working paper Series in Economics No.8, University of New England. 